for a diagnosis of permanent visual handicap: over three in five children with a minor defect at one screening had normal vision at the next (tables I and II). These improvements were probably more apparent than real, being due partly to the technical difficulties of screening children, especially young primary schoolchildren, in ordinary school settings. As children become older they have better powers of concentration and are less easily distracted; younger children, on the other hand, may underperform because they regard screening as a classroom proficiency test and fear making a mistake. Also, children who are found to have a defect at an early age probably undergo regular, subsequent tests and learn to interpret blurred images, obtaining thereby a rather better test result. Also many children with myopia learn to improve their acuity by as much as two lines by peering between half-closed lids, so that without very careful testing they "overperform" at their later examinations.

Regular screening in the school years is therefore essential to detect the early development of visual defects. Such a system requires adequate back-up services for those identified as needing further assessment. So that children may be protected from having unnecessary treatment or glasses, the specialists to whom the children are referred should have an impartial appreciation of the value of glasses, knowledge of developmental ophthalmology, and a systematic and flexible recall programme. These circumstances are not necessarily found in the current National Health Service arrangements outside the school eye service.

\section{References}

${ }^{1}$ Ingram, R M, British Medical fournal, 1973, 1, 278.

2 Gardiner, P A, British Medical fournal, 1973, 1, 552.

${ }^{3}$ Primrose, J, British Medical fournal, 1973, 2, 177.

${ }^{4}$ Ingram, R M, British Medical fournal, 1973, 2, 548.

${ }^{5}$ Gardiner, P A, British Medical fournal, 1977, 2, 577.

'Cameron, H, British Medical fournal, 1977, 2, 701.

Ingram, R M, British Medical fournal, 1977, 2, 890.

* Peckham, C, and Tibbenham, A, British Medical fournal, 1977, 2, 958.

9 Mulholland, W V, British Medical fournal, 1977, 2, 1083.

10 Youngson, R M, British Medical fournal, 1977, 2, 1221.

${ }^{11}$ Butler, N R, and Alberman, E D, Perinatal Problems. Edinburgh, Livingstone, 1969

12 Davie, R, Butler, N R, and Goldstein, H, From Birth to Seven. London, $\overline{\bar{C}}$ Longman, in association with the National Children's Bureau, 1972.

13 Wedge, P J, Concern, 1969, 3, 34.

${ }^{14}$ Fogelman, K, editor, Britain's Sixteen-Year-Olds. London, National@ Children's Bureau, 1976.

${ }^{15}$ Alberman, E D, Butler, N R, and Sheridan, M D, Developmental Medicine $\vec{O}$

and Child Neurology, 1971, 13, 9.
${ }^{16}$ Peckham, C S, and Adams, B, Child Care, Health and Development, 1975, $\overrightarrow{\vec{\omega}}$ 1,93 .

1: Gabriel, F R, Fournal of the American Statistical Association, 1966, 61, 1081 .

1* Douglas, J W B, Ross, J M, and Simpson, H R, fournal of the RoyalStatistical Society, 1967, 130, 479.

${ }^{9}$ Peckham, C S, Gardiner, P A, and Goldstein, H, British Medical fournal, $\vec{N}$ $1977,1,542$.

${ }^{20}$ Brown, M S, Clinical Pediatrics, 1975, 14, 968.

21 Sheridan, M, Developmental Medicine and Child Neurology, 1974, 16, 189. $\vec{\omega}$

\title{
Periurethral aerobic microflora of pregnant and non-pregnant women
}

\author{
INGELA BOLLGREN, VLASTA VACLAVINKOVA, \\ BENGT HURVELL, GUDMUND BERGQVIST
}

British Medical fournal, 1978, 1, 1314-1317

\section{Summary and conclusions}

Seventy-two pregnant and 88 non-pregnant women were examined to see whether the periurethral region had been colonised with group B streptococci (Streptococcus agalactiae), enterococci, and Gram-negative rods belonging to the Enterobacteriaceae. A semi-quantitative method was used for periurethral sampling, and paired urethral swabs were also collected to compare the isolation rates of group $B$ streptococci from the two sites and with the two sampling methods. A higher isolation rate was found with periurethral sampling. Most specimens showed no

\footnotetext{
Department of Bacteriology, National Bacteriological Laboratory, Stockholm, Sweden, and Department of Paediatrics, Karolinska Hospital, Stockholm, Sweden

INGELA BOLLGREN, MD, assistant
}

Department of Gynaecology and Obstetrics, Sabbatsberg Hospital, Stockholm, Sweden

VLASTA VACLAVINKOVA, MD, associate professor

National Veterinary Institute, Stockholm, Sweden BENGT HURVELL, DVM, associate professor

Department of Paediatrics, Central Hospital, Växjö, Sweden GUDMUND BERGQVIST, MD, head of department or scanty growth of Gram-negative rods. Pregnancy was often associated with heavy growth of enterococci. Sampling performed during menstruation and while 0 oral contraceptives were being used produced high isolation rates of group $B$ streptococci.

These results seem to suggest that the periurethral area might protect against genital colonisation with group $B$ 웅 streptococci as it does against urinary tract infection and that hormonal factors influence the carriage of these organisms.

\section{Introduction}

The causal agents of neonatal sepsis and meningitis have changedo over the past 40 years. $\beta$-Haemolytic streptococci of group $A \stackrel{乛}{\Phi}$ were the commonest cause of these infections before 1940, but, $\stackrel{?}{-}$ with the introduction of penicillin, Escherichia coli and other Enterobacteriaceae began to predominate. Since 1960 reports from different countries have incriminated $\beta$-haemolytic $\stackrel{\mathbb{Q}}{\stackrel{9}{\beta}}$ streptococci of group B (Streptococcus agalactiae) along with@ $E$ coli as a major cause of serious neonatal infection. ${ }^{1-4}$ The음 reason for this worldwide emergence of group B streptococci in neonatal disease is unknown. Several studies have shown thato the maternal genital tract is the principal source of infection, at least in the early onset type. "A reasonable hypothesis is that? the microbial flora of the female genital tract has in some way" undergone qualitative or quantitative changes during the last decade, with increased risk of exposing the child to group B streptococci. Attention has been focused on oral contraception 
as a possible cause of changes in the normal flora, ${ }^{6}{ }^{7}$ but no studies have shown any convincing correlation between oral contraceptive use and colonisation of the female genital tract with group B streptococci.

The periurethral and vestibular areas seem to play a part in defence against ascending urinary tract infection. The bacteria that most often cause urinary tract infections-enterobacteria and enterococci-are rarely isolated from these areas in healthy girls and women, ${ }^{*}{ }^{9}$ while infection-prone individuals tend to be colonised in these regions, even during infection-free intervals. $^{\times 10}$

Our study was prompted by the idea that such periurethral and vestibular defence mechanisms also might protect the urogenital tract against colonisation with group B streptococci Accordingly, periurethral carriage of group B streptococci, Gram-negative rods belonging to the Enterobacteriaceae, and enterococci was studied and the influence of factors such as pregnancy, menstruation, and the use of oral contraceptives analysed. A semi-quantitative method was used for obtaining viable counts of bacteria in periurethral samples, and paired urethral swabs were also collected so that the isolation rates of group B streptococci from these two areas and with these different sampling methods could be compared.

\section{Subjects and methods}

Seventy-two pregnant women were examined during a routine check at a motherhood advisory clinic. Samples from 26 of these women were collected before the 28 th week of pregnancy. Eighty-eight non-pregnant women attending a family-planning clinic were also examined. None showed any clinical signs of genital infection. Thirtytwc of these 88 women were examined during the first seven days of menstrual cycle, 55 were examined later in the cycle, and in one information was lacking. Table I shows the age distribution and data about urinary tract infections. Urine specimens were examined for bacteriuria by the nitrite test. Table II records data about the use of contraceptives by the non-pregnant women.

TABLE I-Age distribution and data about urinary tract infections (UTI) for 72 pregnant and 88 non-pregnant women. Results are numbers of women

\begin{tabular}{|c|c|c|c|c|c|c|c|}
\hline & \multicolumn{4}{|c|}{ Age (years) } & \multicolumn{3}{|c|}{ UTI } \\
\hline & $=20$ & -30 & -40 & $>40$ & Current & $\begin{array}{c}\text { During } \\
\text { past } \\
\text { year }\end{array}$ & $\begin{array}{c}\text { During } \\
\text { current } \\
\text { pregnancy }\end{array}$ \\
\hline $\begin{array}{l}\text { Pregnant }(n=72) \\
\text { Non-pregnant }(n=88)\end{array}$ & $\begin{array}{l}2 \\
8\end{array}$ & $\begin{array}{l}44 \\
52\end{array}$ & $\begin{array}{l}26 \\
27\end{array}$ & 1 & & 4 & 6 \\
\hline
\end{tabular}

TABLE II-Data about use of oral contraceptives and intrauterine devices (IUD by 88 non-pregnant women

\begin{tabular}{l|c|c|c}
\hline & At examination & Earlier & Never \\
$\begin{array}{l}\text { No using oral contraceptives } \\
\text { No using IUDs }\end{array}$ & 21 & $21 \quad$ Not known & 27 \\
\hline
\end{tabular}

The aerobic periurethral flora was semi-quantitatively determined. ${ }^{9}$ Briefly, a 5-ml plastic syringe was filled with sterile gelatin and kept at $4 \mathrm{C}$ until used. The needle end of the syringe was cut off. The gelatin, with a cross-sectional area about $1 \mathrm{~cm},{ }^{2}$ was pressed against the urethral orifice. A $2-\mathrm{mm}$ slice $(0.2 \mathrm{ml}$ gelatin with the bacteria-bearing surface) was cut off and dissolved in $1.8 \mathrm{ml}$ of sterile $0.05-\mathrm{M}$ phosphate buffer. Aliquots of $0.1 \mathrm{ml}(1 / 20$ of the total dissolved gelatin sample) were pipetted on to plates with $10 \%$ horse blood agar, cystine-lactoseelectrolyte-deficient agar (CLED, Oxoid), and gentian violet agar with $10 \%$ horse blood. The plates were incubated at $37 \mathrm{C}$ for 48 hours. The gentian violet plates were anaerobically incubated by using the Gas Pak system (BBL). Serial dilutions were prepared when the plate count of different species exceeded 300 colonies per plate. Total counts of different species were recorded as colony-forming units
$(\mathrm{CFU}) / \mathrm{cm}^{2}$. Bacterial growth was regarded as "heavy" when viable counts exceeded $1000 \mathrm{CFU} / \mathrm{cm}^{2}$.

Carriage of group B streptococci, enterococci, and Gram-negative rods belonging to the Enterobacteriaceae was especially studied. Group B streptococci were identified by typical colony appearance, most easily on the anaerobically incubated plates, and tested for their ability to hydrolyse hippurate. ${ }^{11}$ Identification of isolates was verified by the CAMP test ${ }^{12}$ and by streptococcal grouping performed with specific antiserum. ${ }^{13}$ All strains identified as group B streptococci showed $\beta$-haemolysis.

Enterococci were identified by their ability to hydrolyse esculin and growth in $40 \%(\mathrm{w} / \mathrm{v})$ bile and in $6.5 \%(\mathrm{w} / \mathrm{v}) \mathrm{NaCl}$. Enterococci producing black colonies on plates containing potassium tellurite were identified as Str faecalis. ${ }^{14}$

Gram-negative rods belonging to the Enterobacteriaceae were replated from the CLED agar plate. When colony counts exceeded five colonies per plate $\left(100 \mathrm{CFU} / \mathrm{cm}^{2}\right)$ isolates were speciated by API 20 E. ${ }^{15}$

The urethral specimens were collected with cotton-tipped swabs inserted about one $\mathrm{cm}$ into the urethra, put into a transport medium, ${ }^{16}$ and streaked on blood agar plates containing gentian violet. The urethral specimens were investigated only for group B streptococci.

Fisher's exact probability test was used for statistical analysis of the results : $P<0.05=$ almost significant, $P<0.01=$ significant.

\section{Results}

ISOLATION OF GROUP B STREPTOCOCCI FROM PERIURETHRAL AND URETHRAL SAMPLES

Group B streptococci were isolated from $52(33 \%)$ of the 160 women studied (table III). Streptococci were isolated from both periurethral and urethral samples in 32 women, from only the periurethral samples in 15 , and from only the urethral samples in five.

Those paired specimens with positive isolations from only the urethral samples were regarded as revealing "scanty growth"- that is, they were comparable to periurethral samples with viable counts of $\leqslant 1000 \mathrm{CFU} / \mathrm{cm}^{2}$

\section{BACTERIAL COLONISATION OF PERIURETHRAL AND URETHRAL AREAS}

\section{Group B streptococci}

Group B streptococci were isolated from 18 of the 72 pregnant women (table III). Positive specimens were evenly distributed throughout pregnancy: 6 out of $26(23 \%)$ women in early pregnancy had streptococci, compared with 12 out of $46(26 \%)$ in late pregnancy. Specimens showing "heavy growth" ( $\left.>1000 \mathrm{CFU} / \mathrm{cm}^{2}\right)$, however, tended to be more common during the latter part of pregnancy, when 9 out of 12 specimens yielded such counts compared with two out of six during early pregnancy (difference not statistically significant).

TABLE III-Periurethral and urethral colonisation with group B streptococci. Numbers in parentheses indicate women with positive urethral sample and negative periurethral sample

\begin{tabular}{l|r|r|r|r|r|r}
\hline $\begin{array}{c}\text { Periurethral samples } \\
\left(\mathrm{CFU} / \mathrm{cm}^{2}\right)\end{array}$ & 0 & $-10^{2}$ & $-10^{3}$ & $-10^{4}$ & $-10^{5}$ & $>10^{5}$ \\
\hline $\begin{array}{l}\text { Pregnant women } \\
\text { Non-pregnant women }\end{array}$ & $\begin{array}{r}55(1) \\
58(4)\end{array}$ & $\begin{array}{r}1 \\
10\end{array}$ & $\begin{array}{r}5 \\
10\end{array}$ & $\begin{array}{l}6 \\
9\end{array}$ & $\begin{array}{l}2 \\
1\end{array}$ & 3 \\
\hline
\end{tabular}

Group B streptococci were isolated from 34 of the 88 non-pregnant women (table III). The carrier rate was $56 \%$ in the 32 women who were examined during the first week of menstrual cycle compared with $27 \%$ among 55 women from whom samples were collected later during the cycle $(P<0.05)$ (table IV). There were no differences in bacterial counts during the cycle.

The frequency of isolation of group B streptococci in relation to the use of oral contraceptives is shown in table IV. During the first week of the menstrual cycle there were no significant differences between women taking oral contraceptives and women who had never used these pills. Later in the cycle group B streptococci were found in 11 of the 29 wome $a$ who were taking contraceptives when sampling was 
TABLE IV-Periurethral and urethral colonisation with group $B$ streptococci according to period of menstrual cycle and oral contraceptive use. Results are numbers of women colonised out of number in each group

\begin{tabular}{c|c|c|c}
\hline \multirow{2}{*}{ Days of cycle } & \multicolumn{3}{|c}{ Oral contraceptive use: } \\
\cline { 2 - 3 } & Never & Earlier & At examination \\
\hline $1-7$ & $5 / 11$ & $7 / 11$ & $6 / 10$ \\
$8-30+$ & $1 / 16$ & $3 / 10$ & $11 / 29$ \\
\hline
\end{tabular}

performed but in only one of the 16 women who had never used oral contraceptives $(P<0.05)$. The latter woman and two of the three ex-takers who were not menstruating and who were colonised with group B streptococci had had intrauterine devices inserted.

\section{Gram-negative rods}

Gram-negative rods belonging to the Enterobacteriaceae were isolated from 17 of the 72 pregnant women and 14 of the 88 nonpregnant women (table V). Eighteen specimens showed $>100 \mathrm{Gram}-$ negative bacteria $/ \mathrm{cm}^{2}$. Further bacteriological analyses performed on isolates from these samples showed $E$ coli in 16 of them.

Most of the non-pregnant women yielded no Gram-negative rods; the few with heavy colonisation were menstruating. Seven pregnant women showed heavy growth. Some months later one of these women acquired a urinary tract infection with $E$ agglomerans, the same species with which she had been colonised. The six women who had had urinary tract infections earlier during pregnancy were completely free of Gram-negative bacteria in the periurethral samples.

TABLE V-Viable counts of Gram-negative rods and enterococci in the periurethral samples from 72 pregnant and 88 non-pregnant women. Results are numbers of women

\begin{tabular}{|c|c|c|c|c|c|c|}
\hline \multirow[b]{2}{*}{ Counts $\left(\mathrm{CFU} / \mathrm{cm}^{2}\right)$ : } & \multicolumn{3}{|c|}{ Gram-negative rods } & \multicolumn{3}{|c|}{ Enterococci } \\
\hline & 0 & $\leqslant 1000$ & $>1000$ & 0 & $\leqslant 1000$ & $>1000$ \\
\hline $\begin{array}{l}\text { Pregnant } \\
\text { Non-pregnant }\end{array}$ & $\begin{array}{l}55 \\
74\end{array}$ & $\begin{array}{l}10 \\
12\end{array}$ & $\begin{array}{l}7 \\
2\end{array}$ & $\begin{array}{l}42 \\
72\end{array}$ & $\begin{array}{l}13 \\
15\end{array}$ & $\begin{array}{r}17 \\
1\end{array}$ \\
\hline
\end{tabular}

\section{Enterococci}

Ninety-eight per cent of the enterococci were Str faecalis. Periurethral carriage of enterococci was found in 30 of the pregnant women and in 16 of the non-pregnant group (table V). Significantly, heavy growth $\left(>1000 \mathrm{CFU} / \mathrm{cm}^{2}\right)$ was shown in 17 of the pregnant and only in one of the non-pregnant women $(P<0.01)$. Colonisation was not correlated with the duration of pregnancy, the use of oral contraceptives, or the phase of menstrual cycle.

\section{Discussion}

This investigation has shown that sampling performed during menstruation and while oral contraceptives were being used was associated with high isolation rates of group B streptococci in the periurethral and urethral areas. Pregnancy was often associated with a heavy periurethral colonisation with enterococci.

Sampling from the periurethral area with a semi-quantitative method for obtaining viable counts of bacteria yielded a higher isolation rate of group B streptococci than the conventional sampling technique with swabs from the urethra, which has so far been considered to be the best single site for detecting genital group B streptococci. ${ }^{17}$ This periurethral sampling method has the added advantage of not introducing bacteria into the vagina on either the swab or a speculum in pregnant women. In accordance with other reports our investigation also showed that paired samples from different sites yielded even higher carrier rates than a sample from a single site.

The periurethral region and the vaginal introitus probably present a barrier to ascending urinary tract infections, where the infecting organism, mainly $E$ coli, emanates from the faecal reservoir. ${ }^{81018}$ The genital tract has been considered to be the primary site of group B streptococcal colonisation, ${ }^{2}$ but recent studies suggest that the intestinal tract might be the primary reservoir even for this organism. ${ }^{19}$ The genital tract is probably also colonised in an ascending manner, as the highest isolation rates of group B streptococci have been reported from the vulva and lowest from the cervix. ${ }^{20}$

The changed hormonal balance during pregnancy might be reflected by a changed local microbial flora, such as an increased incidence of Candida albicans. ${ }^{21}$ In this study the most evident effect of pregnancy on the local bacterial flora was the frequent isolation of enterococci.

The results from the non-pregnant women who had never used oral contraceptives show that the isolation rate of group $B$ streptococci peaked during the first week of the menstrual cycle, when about half the women were colonised compared with only $6^{\circ}{ }_{0}$ later during the cycle. A possible interpretation might be that physiological periurethral defence mechanisms change during menstruation, permitting temporary colonisation with group B streptococci from the anorectal area. Since most studies of the carrier rates of group B streptococci have not stated the time of sampling in relation to the menstrual cycle, our findings might explain partly the great variations in the frequencies of isolation reported. Baker's findings of a higher carrier rate of group B streptococci during the first two weeks of the menstrual cycle accords with our findings. ${ }^{22}$

Menstruation also seemed to favour the presence of $E$ coli, but not an increase in enterococci. Practically, these findings suggest that menstruation is not the best time for endocervical instrumentation such as insertion of intrauterine devices.

In this study group B streptococci were isolated more often from women using oral contraceptives than from women who never had used oral contraceptives, provided that the samples were collected after the first week of the menstrual cycle. The group who had previously used oral contraceptives was so heterogeneous with respect to the time that had elapsed since they stopped taking anovolants that no meaningful conclusions could be drawn. Some of these ex-takers who were colonised with group B streptococci were using intrauterine devices, which might have promoted colonisation. ${ }^{22}$

Christensen et al pointed out that group B streptococci might be sexually transmitted, as these streptococci were significantly more common in patients from whom Neisseria gonorrhoeae was also cultured than in patients without gonorrhoea. ${ }^{23}$ In contrast, Wallin et al found no correlation between carriage of $N$ gonorrhoeae and carriage of group B streptococci. ${ }^{24}$ One reason for the increased incidence of group B streptococci in our study among women using oral contraceptives might be that their sexual activity was different from that of women who had never used the pill. But the finding that the two groups did not differ in carrier rate during menstruation seems to contradict this explanation (table IV).

Another reason for the differences might be that oral contraceptives influence the microbial flora of the genital tract. Few reports concern this side effect of contraception apart from several studies that have shown an increased incidence of vaginal $\mathbb{\Phi}$ carriage of Candida albicans in women taking oral contraceptives. ${ }^{25}$ This has been attributed to the oestrogenic component, which increases the glycogen content of vaginal cells, forming a suitable milieu for candida. Such local changes would probably affect the normal bacterial flora too. Oral contraceptives influence both general and local immune mechanisms, ${ }^{26} 2$ : which might also be reflected in changes in the local flora.

In conclusion. it seems reasonable to assume that the periurethral region helps to defend against genital colonisation with group B streptococci from the intestinal tract. These defence $\stackrel{\rightleftharpoons}{\rightleftharpoons}$ mechanisms might also be influenced by pregnancy, menstruation, and use of oral contraceptives. Indeed, our results suggest that oral contraceptives influence the periurethral area so that group B streptococci can colonise more readily. Whether 
or not similar influences are exerted on the vaginal-cervical bacterial flora remains to be investigated.

Financial aid for this study was provided by the Medical Research Council (grant 19X-765) and the Expressen Foundation for Prenatal Research.

Requests for reprints should be addressed to Dr I Bollgren, Department of Paediatrics, Karolinska Hospital, S-10401 Stockholm, Sweden.

\section{References}

${ }^{1}$ Hood, M, Janney, A, and Dameron, G, American Fournal of Obstetrics and Gynecology, 1961, 82, 809.

2 Eickhoff, T C, et al, New England fournal of Medicine, 1964, 271, 1221.

${ }^{3}$ Bergqvist, G, et al, Scandinavian Fournal of Infectious Diseases, 1971, 3, 157.

${ }^{4}$ Franciosi, R A, Knostman, J D, and Zimmerman, R A, fournal of Pediatrics, 1973, 82, 707.

Baker, C J, and Barrett, F F, Fournal of Pediatrics, 1973, 83, 919.

${ }^{6}$ McCracken, G H, fournal of Pediatrics, 1973, 82, 703.

7 Wilson, H D, and Eichenwald, H F, Pediatric Clinics of North America, 1974, 21, 571 .

${ }^{8}$ Stamey, T A, et al, California Medicine, 1971, 115, 1.

${ }^{9}$ Bollgren, I, and Winberg, J, Acta Paediatrica Scandinavica, 1976, 65, 74.
${ }^{10}$ Bollgren, I, and Winberg, J, Acta Paediatrica Scandinavica, 1976, 65, 81. ${ }^{1}$ Hallmann, L, Bakteriologie und Serologie. Stuttgart, Georg Thieme Verlag, 1961.

12 Christie, R, Atkins, N E, and Munch-Petersen, E, Australian fournal of Experimental Biology and Medical Science, 1944, 22, 197.

${ }_{13}$ Lancefield, R C, Fournal of Experimental Medicine, 1933, 57, 571.

14 Facklam, R R, Applied Microbiology, 1973, 26, 138.

15 Nord, C-E, Lindberg, A A, and Dahlbäck, A, Medical Microbiology and Immunology, 1974, 159, 211.

16 Gästrin, B, Kallings, L O, and Marcetic, A, Acta Pathologica et Microbiologica Scandinavica, 1968, 74, 371.

17 Bergqvist, G, et al, Scandinavian fournal of Infectious Diseases, 1971, 3, 209.

18 Grüneberg, R N, Lancet, 1969, 2, 766.

19 Badri, M S, et al, Fournal of Infectious Diseases, 1977, 135, 308.

${ }^{20} \mathrm{Kexel}, \mathrm{G}$, and Beck, K J, Geburtshilfe und Frauenheilkunde, 1965, 25, 1078.

21 Jones, C P, and Martin, D S, American fournal of Obstetrics and Gynecology, 1938, 35, 98.

22 Baker, C J, et al, fournal of Infectious Diseases, 1977, 135, 392.

${ }^{23}$ Christensen, K K, et al, Scandinavian Fournal of Infectious Diseases, 1976, $8,75$.

${ }^{24}$ Wallin, J, and Forsgren, A, British Fournal of Venereal Diseases, 1975, 51, 401.

25 Catterall, R D, Lancet, 1966, 2, 830

${ }^{26}$ Joshi, U M, et al, Contraception, 1971, 3, 327.

27 Chipperfield, E J, and Evans, B A, Infection and Immunity, 1975, 11, 215.

(Accepted 15 March 1978)

\title{
Prevention of secondary cases of meningococcal disease in household contacts by vaccination
}

\author{
B M GREENWOOD， M HASSAN-KING， H C WHITTLE
}

British Medical fournal, 1978, 1, 1317-1319

\section{Summary and conclusions}

Household contacts of patients with group A meningococcal infection were vaccinated with either meningococcal vaccine or tetanus toxoid. Five of the 523 subjects who received tetanus toxoid developed meningococcal meningitis and another four probably had meningococcal disease. Only one possible case of meningococcal infection occurred among 520 contacts vaccinated with meningococcal vaccine. Vaccination had no effect on nasopharyngeal carriage of meningococci.

Vaccination of household contacts of patients with group A meningococcal infections is an effective way of using limited supplies of meningococcal vaccine, though its value would be limited in an epidemic. Secondary cases of meningococcal infection often occur within a few days of the index case, and, although vaccine alone seemed to provide adequate prophylaxis in these Nigerian subjects, additional chemoprophylaxis may be needed to cover this critical period.

\section{Introduction}

Family contacts of patients with meningococcal meningitis or septicaemia have an increased chance of contracting the disease.

Department of Medicine, Ahmadu Bello University, Zaria, Nigeria B M GREENWOOD, FRCP, senior lecturer in medicine M HASSAN-KING, MSC, senior technologist

H C WHITTLE, MRCP, senior lecturer in medicine
A recent nationwide survey in the United States showed that the attack rate among household contacts of patients with the endemic form of the infection was approximately 3 per $1000 .^{1}$ In Los Angeles during 1963-6 the attack rate among household contacts of people with sporadic infection was about 10 per 1000. ${ }^{2}$ Higher secondary attack rates, however, ranging from 11 per 1000 to 59 per 1000 , have been recorded in the United States during epidemics. ${ }^{3-6}$ The secondary attack rate during an epidemic of group A meningococcal disease in Chile was 25 per $1000,{ }^{7}$ and during a more recent epidemic of predominantly group $\mathrm{C}$ infection in Brazil it was 16 per $1000 .{ }^{8}$ We have found no report on the incidence of secondary cases during the epidemics of meningococcal infection that often affect the savanna region of tropical Africa.

Because of their increased likelihood of contracting the in 'ection family contacts of patients with meningococcal disease are usually given some form of chemoprophylaxis. Sulphonamides have been widely and successfully used for this purpose bit they can no longer be relied on because of the emtrgence of sulphonamide-resistant meningococci. Minocycline and ::fampicin prevent carriage in household $\operatorname{contacts}^{6}$ but it has yet to be definitely established that they can prevent secondary cases of the disease. ${ }^{9}$ We therefore studied whether vaccination could be used as an alternative form of prophylaxis for close contacts of patients with meningococcal infection.

\section{Patients and methods}

During March-May 19771003 patients with meningococcal disease were admitted to Ahmadu Bello University Hospital, Zaria, Nigeria. In nearly all cases the causative organism was a group A sulphonamideresistant meningococcus.

Meningococcal infection was diagnosed when meningococci were cultured from blood or cerebrospinal fluid (CSF) or when meningococcal antigen " as detected in serum or cerebrospinal fluid by counter- 